\title{
INVESTIGATING STUDENTS ACCEPTANCE OF E- LEARNING USING TECHNOLOGY ACCEPTANCE MODEL AMONG DIPLOMA IN OFFICE MANAGEMENT AND TECHNOLOGY STUDENTS AT UITM MELAKA
}

\author{
Siti Rosnita Sakarji ${ }^{1}$ \\ Faculty of Business and Management, \\ Universiti Teknologi MARA, Melaka \\ (Email: rosnita507@uitm.edu.my) \\ Khalijah Binti Mohd Nor ${ }^{2}$ \\ Faculty of Business and Management, \\ Universiti Teknologi MARA, Melaka \\ (Email: khalijah904@uitm.edu.my) \\ Masliza Mohd. Razali ${ }^{3}$ \\ Faculty of Business and Management, \\ Universiti Teknologi MARA, Melaka \\ (Email: maslizarazali@uitm.edu.my) \\ Nashrah Talib ${ }^{4}$ \\ Faculty of Business and Management, \\ Universiti Teknologi MARA, Melaka \\ (Email: nashrah622@uitm.edu.my) \\ Nurbarirah Ahmad ${ }^{5}$ \\ Faculty of Business and Management, \\ Universiti Teknologi MARA, Melaka \\ (Email: nurbarirah497@uitm.edu.my) \\ Wan Aisyah Amni Wan Mohamad Saferdin \\ Faculty of Business and Management, \\ Universiti Teknologi MARA, Melaka \\ (Email: aisyah606@uitm.edu.my)
}

Accepted date: 13-03-2018

Published date: 09-07-2019

To cite this document: Sakarji, S. R., Nor, K. M., Razali, M. M., Talib, N., Ahmad, N., \& Saferdin, W. A. A. W. M. (2019). Investigating Students Acceptance of E-Learning Using Technology Acceptance Model Among Diploma in Office Management and Technology Students at UiTM Melaka. Journal of Information System and Technology Management, 4(13), 13-26.

DOI: $10.35631 / J I S T M .413002$

Abstract: The Industrial Revolution 4.0 (IR 4.0) has given a new impetus to educational transformation. In recent years, education experts recognise the profound impact that a myriad of technological innovations in ICT is having on education. They agree that education 4.0 will be shaped by innovations and will indeed have to train students to produce innovations. E-learning has become an increasingly popular learning approach in higher education institutions (HEIs) due to the rapid growth of Internet technologies in Malaysia. The technology acceptance model (TAM) proposes that perceived ease of use and 
perceived usefulness predict applications usage. It has been integrated in many university programs and is one of the new learning trends. The study aims to investigate students' acceptance towards e-learning system using Technology Acceptance Model (TAM). The study was conducted to the students that undergone the Diploma in Office Management and Technology programme from Faculty of Business and Management, UiTM Melaka. The purpose of the study conducted was to investigate the level of students' acceptance in terms of ease of use and perceived usefulness of e-learning. A set of questionnaires was used for data collection. Descriptive statistics were used to describe the demographic characteristics of the study respondents. All analysis was performed by using SPSS. A total of 50 students completed the survey questionnaire with a satisfactory response rate. It was found that the perceive ease of use and perceived usefulness has a significant effect on attitude toward $e$ learning. The respondents agreed that e-learning is very useful and makes them easier to study the course content. Students are found to be frequently engaged in using e-learning and believed it enhancing their academic performances. The outcomes will enrich the understanding of students' acceptance of e-learning and will assist in its continuing implementation at UiTM Melaka.

Keywords: Technology Acceptance Model, Perceived Ease of Use, Perceived Usefulness, Attitude Toward Using, Behavioral Intention to Use

\section{Introduction}

The Industrial Revolution 4.0 (IR 4.0) has given a new impetus to educational transformation. In recent years, education experts recognise the profound impact that a myriad of technological innovations in ICT is having on education. This embracing Education 4.0 had shaped by innovations and indeed has to train students to produce innovations. In this context, it is vitally important to impart appropriate education to the future workforce. Based on the trends so far, researchers predict that IR 4.0 will necessitate profound changes in major aspects of education: content, delivery/pedagogy, and structure/management of education. IR 4.0 demands changes in the contents of not only technical education, but also education in general. Across disciplines, new emphasis would have to emphasize on certain skills and new contents have to be added. The introduction and expansion of new technologies in the context of the Fourth Industrial Revolution has led to the emergence of new professions and new ways of working, which has also been reflected in the formulation of new requirements regarding preferred knowledge and skills of staff associated with different modes of preparation and behavior patterns than in traditional professions. Greater emphasis is put on lifelong learning, self-management, and the development of human potential. In addition to professional IT competencies (work with databases and expert systems, data analysis, etc.) and other technical disciplines, the vision of Education 4.0 is associated with the requirements of creativity, independence, cooperation, development of social competences, such as communication and presentation skills, team work ability, management skills, etc. Education 4.0 is used in the sense of training people for the needs of Industry 4.0 (Janikova \& Kowalikova, 2017). Therefore, new educational program would need to be developed to meet changing demands. Innovations such as mobile computing, cloud, social network and big data have created an opportunity to build a learning ecosystem that allows personalized learning which is independent of time and place. Learners will be able to design their own educational pathways based on their personal goals. Meeting increasing demand for ubiquitous mobile learning will require the use of Massive Open Online Courses, virtual classroom, remote labs, virtual labs and game- 
based learning as important tools. This is supported by Keirl (2015) that emphasizes combining different cases in technology education, such as human and technology, natural and artificial, and visible and invisible, in order to extract basic concepts in technology education curriculum. One of the binaries in the studies of Keirl is whether the universities and technology education seek to make changes or maintain the status quo and whether technology education is just about using tools and technical skills or technological behaviors. Gebhard (2015) perceived that Industry 4.0 is known as the factory of the future that implies that most of the processes and products are digitalized and automated.

Education 4.0 is to address the issues and challenges of the fourth industrial revolution and is more specific than the Malaysia Education Blueprint 2015-2025 (Higher Education). The Malaysia Education Blueprint 2015-2025 (Higher Education) has already incorporated elements meant to tackle the uncertainty of the fourth industrial revolution. The foundation for individual student aspirations in the blueprint had highlighted the two (2) important elements that is the importance of ethics and morality and knowledge and skills. A program such as Ceo at Faculty program, (Accreditation of Prior Experiential Learning (APEL), Massive open online course (MOOC), Two University Two Industry (2U2I), Modular Stackable Technical and Vocational Education and Training (TVET), and Integrated Cumulative Grade Point Average (iCGPA) was a few quality programs had been developed as an aspiration for supporting the embracing Education 4.0.

In a study conducted by Hermann, M., Kagermann et. al. (2015), IR 4.0 is defined as "a collective term for technologies and concepts of value chain organisation which draws together Cyber-Physical Systems, the Internet of Things, and the Internet of Services." It is agreed and added by Lavanya B et. al.(2017) that defined Industry 4.0 is a new interdisciplinary field combining cyber-physical systems, the Internet of Things and Services and smart factories.

The Information Technology and Communication (ICT) was become one of the important foundations in Malaysia before the I.R 4.0 had taken place. ICT that shift a productionbased economy to a knowledge base one by the Year 2020 (Multimedia Development Corporation, 2005). In line with the objectives, the implementation of technology in the teaching and learning were widely dispersed in school, college and university level. Arising from the plan, the Smart School Pilot Project was initiated in 1999 where 87 schools were transformed into smart school (Wong \& Teo, 2009). The project emphasized a technologysupported education system and was introduced the need for an ICT literate population (Wong, Kamariah \& Tang, 2006). A study conducted by Multimedia Development Corporation, 2006) revealed that approximately $90 \%$ of the students were found to be competent to use the ICT facilities in classrooms and computer laboratories for meaningful learning. Students were also able to work as a team and engage in peer learning within ICT enriched learning environment. The study also reported that teachers were confident enough to integrate ICT into their teaching-learning process with nearly $83 \%$ of the teacher found to possess a high level of ICT competency (Multimedia Development Corporation, 2006). To date, the use of electronic learning (e-learning) is increasingly prevalent in many higher educational educations (HEIs) or universities in Malaysia (Maslin, 2007). It was supported by a study conducted from Open University Malaysia (OUM) (2004) whereby the previous researchers found that a growing number of public and private universities throughout the nation are employing e-learning methodologies either to offer academic programs via distance or to support their full-time on-campus learners. In studies (Greenhow et al., 2009), 
we can find out that more students use modern technical equipment. Serious research on the influence of education technology on cognitive processes was conducted by Kaufman, 2004; Lee et al., (2008). With the development of information and communication technology, especially computers, a number of researchers (Morrison et al., 2010) were trying to see the benefits and the effect of their use compared to older traditional learning.

Jenkins \& Hanson (2003) defined e-learning as the learning facilitated and supported through the utilization of information and communication technologies (ICTs). Meanwhile Asabere and Enguah (2012) defined e-learning as according to the contexts and environments where it operates. The usage of e-learning may be found in varies form such as Internet, computer, telephone, radio, video and others. Hence, students can use technology to receive class notes or information, take assessments and communicate whenever and wherever the need arises (Maslin, 2007). On the other hand, Concannon, Flynn \& Campbell (2005) found that the factors of this tremendous trend are changes in students' demographic factors, in educational delivery market conditions, and in innovation technology itself. The study conducted by Yi \& Hwang (2003) discovered that there is crucial to identify the critical factors related to user acceptance of technology as there is a growing reliance on information systems and increasing rapidly of the introduction of new technology into learning environment. It also refers to the other study that conducted by Amir, et.al (2013) revealed that universities through effective implementation of e-learning could attract and engage larger numbers of students. Besides, Park (2009) agreed that exploring students' intentions and investigating the factors that impact on students' belief about e-learing can help management to create new methods for attracting a larger number of students who are willing to be involved in e-learning systems. According to Smedley (2010) reported that the measurement of impact from enhancing knowledge management using technology is of a constant interest and importance.

Consecutively, there should be a depth understanding of how students perceive and react to elements of e-learning along with how to most effectively apply an e-learning approach to enhance learning (Koohang \& Durante, 2003). According to Sung (2009) in his study stressed the importance of knowing students' intentions and understanding were the factors that influence students' belief about e-learning because it can help academic administrators and the policy makers to create mechanisms for attracting more students to adopt this learning environment (Grandon, Alshare \& Kwan, 2005). Considered the previous studies conducted by previous researchers in e-learning, the researcher found that it is crucial to investigate issues that explain students' acceptance, intention and attitude towards using elearning system especially in public higher learning institution in Malaysia. However, little research has been done in Malaysia to empirically determine the relationship of university students' e-learning use with personal factors such as perceived usefulness, easiness, attitude, intention to use, and system accessibility. In this paper, the theoretical framework of university students' e-learning acceptance and intention to use technology is based on the technology acceptance model (TAM). TAM used to investigate the acceptance of various information system applications (Chen, S., Li, C. (2011). It considers the impact of perceived ease of use and perceived usefulness on students' intention and attitude to use elearning in their education.

Since the use of personal computers nowadays is part of our everyday life, ICT and Internetbased tools have become valid parts of many learning environments (Landry et al. 2006). However, there are still certain issues that can hinder e-learning unfolding its benefits to 
universities, students and teachers. According to Mallak (2001) such hinders include the adoption rate of e-learning systems, but also costs and infrastructure requirements of an elearning system. If not well planned and designed universities can spend an awful lot of money on new technologies and applications that in the end turn out to be a waste of money and time. It is crucial for universities to know if the shift to ICT-based learning and the services coming out of that really is what their students (and teachers) want and appreciate (Mallak 2001).

In addition, Landry et. al. (2006) state that as education through applying the online becomes more interactive it is extremely important for designers of such systems to know what students value and what they find useful. Keller \& Cernerud (2002) and others call for research on students' perspectives of e-learning systems in higher education with a particular focus on determinants of such perceptions. Yet, much of the literature on e-learning is more of a description on what the teacher could do or has done online, while the students' experience of those activities goes largely undocumented (Shirley 2001; Keller \& Cernerud 2002). Most of the literature found on e-learning is more of descriptive nature and very practice-based as well as the focus often is on the technology or system itself rather than on theoretical contributions and implications (Nichols 2003).

Therefore, this study attempts to investigate students' acceptance of e-learning by using technology acceptance model at UiTM Melaka by selected construct such as their attitude, perceived usefulness, perceived ease of use and intention to use the system. Thus, some research questions were developed:

1. What is the level of students' acceptance in terms of ease of use and perceived usefulness of e-learning?

2. Is there any significant relationship between perceived ease of use and perceived usefulness of learning toward attitude of using e-learning?

\section{Literature Review}

\section{Technology Acceptance Model (TAM)}

The technology acceptance model (henceforth TAM) was first introduced by Davis (1989) based on the theory of reason action (TRA) (Fishbein \& Ajzen, 1975) in psychology research. The other scholars Maslin (2007) reported the slight differences between these two elements in which TRA states that one's behaviour and the intent to behave is a function of one's attitude toward the behaviour and their perceptions about the behaviour. TRA is based on the premise that intention is the main determinant of a person's actions or actual behaviour. Two constructs influence a person's behavioural intention: attitude toward a behaviour and subjective norm or social pressure to carry out the behaviour or not. In TRA the beliefs and evaluations affecting attitude refer to what the individual thinks about the consequences that could arise from the behaviour as well as the personal evaluation of desirability of these consequences. Normative beliefs and motivation to comply (which affect subjective norm) would be understood as the opinion of the reference group versus the motivation of the individual to act in accordance with that opinion. The TRA was designed to explain human behaviour in general; it could be applied to a wide variety of contexts (Davis et al. 1989). Therefore, behaviour is the function of both attitudes and beliefs. TRA is presented in Figure 1 below. 


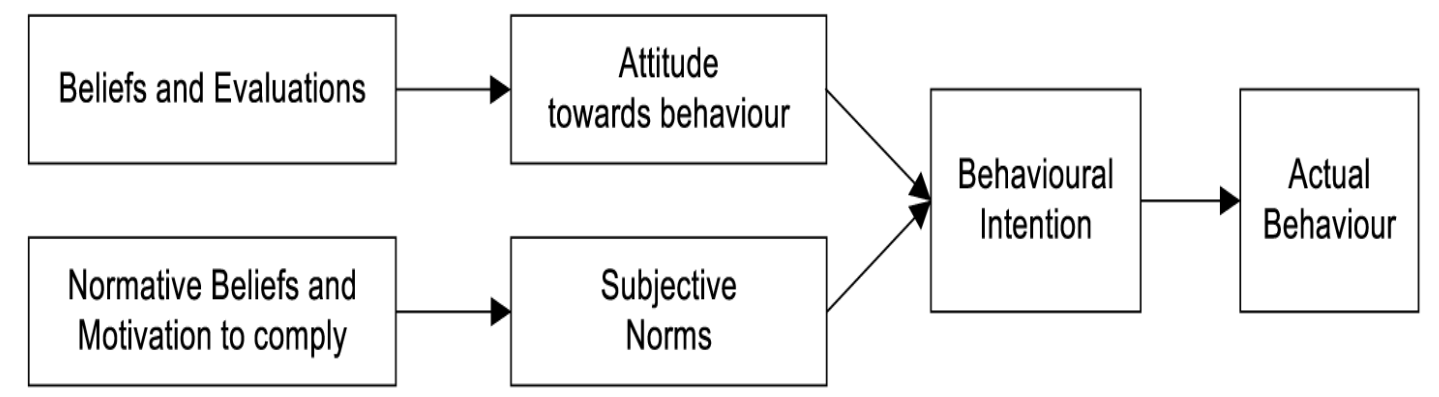

Figure 1: Theory of Reasoned Action, Fishbein \& Ajzen, 1975)

Meanwhile, TAM proposed that perceived ease of use and perceived usefulness of technology are prectors of user attitude towards using the technology, subsequent behavioural intentions and actual usage. Perceived ease of use was also considered to influence perceived usefulness of technology. The original version of TAM (Davis, 1989) was presented in Figure 2 below.

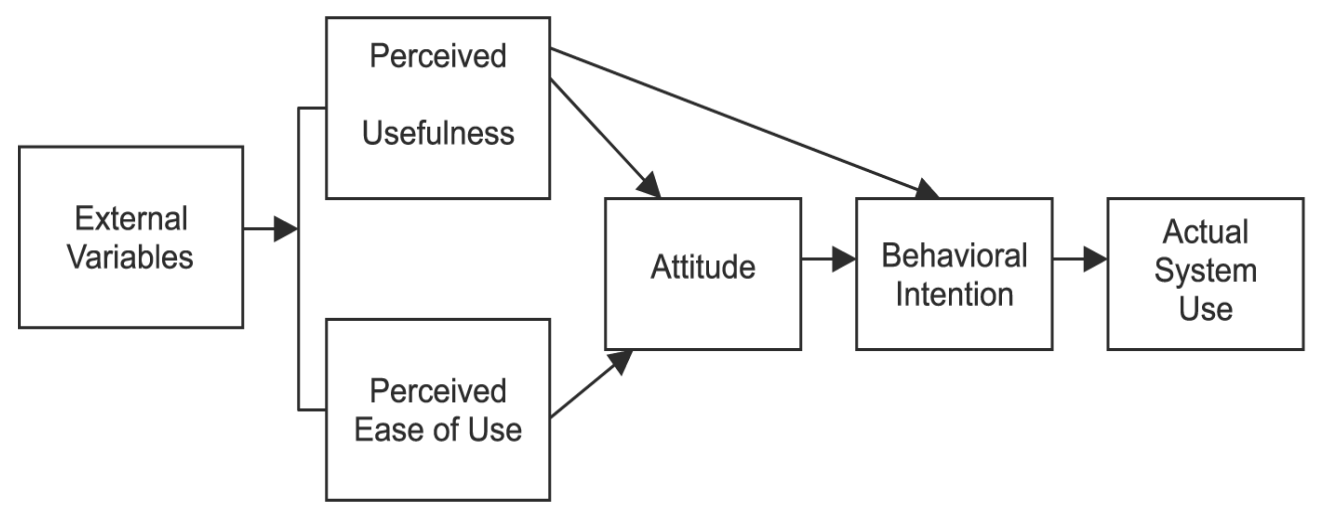

Figure 2: Technology Acceptance Model (Adapted from Davis, Bagozzi \& Warshaw, 1989)

TAM is one of the most influential extensions of Ajzen and Fishbein's theory of reasoned action (TRA) in the literature (Chokri, 2012). It was developed by Fred Davis and Richard Bagozzi (Davis 1989, Bagozzi\& Warshaw 1992). TAM replaces many of TRA's attitude measures with the two technology acceptance measures: ease of use, and usefulness. TRA and TAM, both of which have strong behavioral elements, assume that when someone forms an intention to act they will be free to act without limitation. In the real world there will be many constraints, such as limited freedom to act (Bagozzi\& Warshaw 1992).

The theory of TAM was further enhanced through Maslin (2007) by stating that TAM has been applied in numerous studies testing testing user acceptance of information technology, for example, word processors (Davis et al., 1989), spreadsheet applications (Mathieson, 1991), e-mail (Szajna, 1996), web browser (Morris \& Dillon, 1997), telemedicine (Hu et al., 1999), websites (Koufaris, 2002), e-collaboration (Dasgupta, Granger \& Mcgarry, 2002), and blackboard (Landry, Griffeth \& Hartman, 2006). In this study, the e-learning was considered as a system that makes use of Internet and web technology in accomplishing its mission of delivering information to and interacting with the students through a computer interface. Consequently, several researchers have replicated Davis's original study (Davis 
1989) to provide empirical evidence on the relationships that exist between usefulness, ease of use and system use (Adams, Nelson \& Todd 1992; Davis 1989; Hendrickson, Massey \& Cronan 1993; Segars \& Grover 1993; Subramanian 1994; Szajna 1994). Much attention has been given to testing the robustness and validity of the questionnaire instrument used by Davis. Adams and al. (Adams 1992) replicated the work of Davis (Davis 1989) to demonstrate the validity and reliability of his instrument and his measurement scales. They also extended it to different settings and, using two different samples, they demonstrated the internal consistency and replication reliability of the two scales. In addition, Hendrickson and al. (Hendrickson, Massey \& Cronan 1993) found high reliability and good test-retest reliability. Furthermore, Szajna (Szajna 1994) found that the instrument had predictive validity for intent to use, self-reported usage and attitude toward use. The validity of the instrument designed by Davis is confirmed through researches and has supported its use with different populations of users and different software choices.

In TAM, perceived usefulness refers to the degree to which the user believes that using the technology will improve his or her work performance, while perceived ease of use refers to how effortless he or she perceives using the technology will be. Both of the elements are considered distinct factors influencing the user's attitude towards using the technology, though perceived ease of use is also hypothesized to influence perceived usefulness and attitude towards using the technology. (Maslin, 2007). Finally, such attitude towards using the technology determines the behavioural intention to use that technology. Figure 3 depicts the research model employed in the study. It is a reduced TAM model, excluding actual system use. The external variables constructs are also not included in the research model as there is no immediate intention to examine antecedents to perceived usefulness and perceived ease of use.

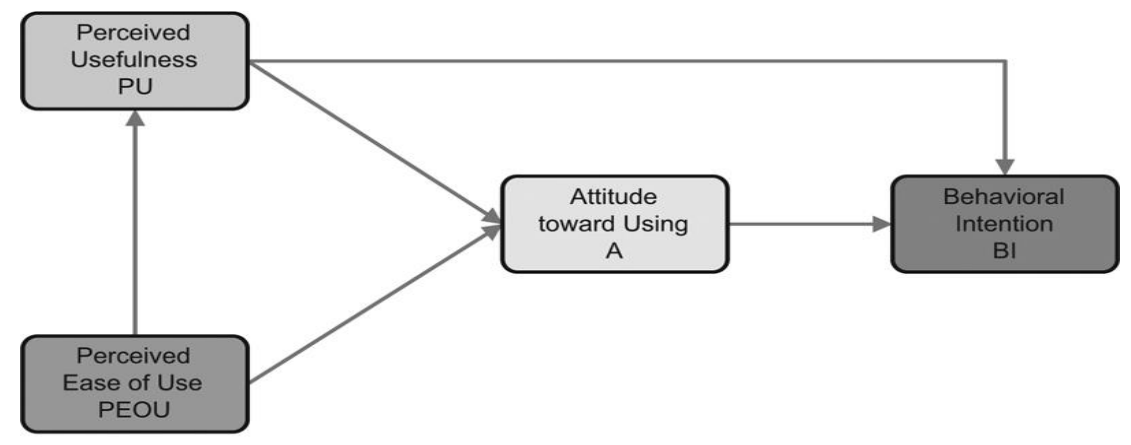

\section{Figure 3: The Research Model (A Technology Usage Model for E-Learning)}

Therefore, the research hypotheses based on the diagram of the TAM model in the context of the e-learning system are:

H1: Perceived ease of use has a significant effect on attitude towards using e-learning. $\mathrm{H} 2$ : Perceived usefulness has a significant effect on attitude towards using e-learning.

\section{Methodology}

In an effort to determine the influencing factors of students' positive opinion about the use of e-learning in learning and teaching and to find possible solutions for these factors, a survey was conducted with a group of second year student (semester 3) $(\mathrm{N}=120)$ students 
from the university during the academic year 2014. The participants in this study consisted of undergraduate students in the field of management and pursuing the e-learning module in the e-learning environment. A survey was conducted on students under Faculty of Business and Management, Universiti Teknologi MARA, Melaka to evaluate the application of TAM to the e-learning system. As agreed by Amer et. al (2013), this study avoided science and computing departments, where students were more likely to be familiar with technology and computer applications. UiTM had started implementing the use of e-learning (that is i-Learn System) for a couple of years. The major aim is to assist faculty in the delivery of courses. Using this system, instructors (lecturers) are able to post course outlines, schedules, and lecture notes on the systems for students. The subjects were drawn from among diploma students $(\mathrm{N}=120)$ who were using the e-learning in their courses. However, only 92 students were selected based on the appropriate sample size from Kerjcie and Morgan (1970) as respondents of this study by using stratified random technique. Each participant was asked to fill out a questionnaire indicating his or her agreement or disagreement with each statesman on a 5-point Likert-type scale with the end points being "strongly disagree" and "strongly agree". Scale items appearing on the survey were adapted from scales measuring variables in Davis et al. (1989). The measurement items used in this study are shown in Appendix.

\section{Findings and Discussion}

Out of 92 questionnaires distributed, only 50 were completed and returned, showing that a 54 percent response rate. Most of the respondents are female (88\%), 18-19 years old. More than average of the respondents $(62 \%)$ had used e-learning more than 1 year with the more than 4 courses taken during their study. Most of the respondents $(64 \%)$ have an internet access in their home and they browse the internet almost once and twice a day.

Table 1: Cronbach's Alpha Result

\begin{tabular}{|c|c|c|}
\hline Variables & n & Cronbach's alpha \\
\hline Perceived Ease of Use (PEOU) & 5 & .865 \\
\hline Perceived Usefulness (PU) & 5 & .867 \\
\hline Attitude Toward Usage (ATT) & 5 & .869 \\
\hline Behavioural Intention (BI) & 4 & .890 \\
\hline
\end{tabular}

Cronbach's alpha is a measure of internal consistency, that is, how closely related a set of items are as a group. A "high" value of alpha is often used (along with substantive arguments and possibly other statistical measures) as evidence that the items measure an underlying (or latent) construct. The result of Cronbach's alpha should be .700 or greater as it shows that the contents of questionnaire is reliable. The reliability coefficient is above 0.70 (Nunnally, 1978). Table below show the results are above .70 thus it can be indicated that the questionnaires are reliable.

Most of the students perceived that e-learning is easy to use (Mean=3.8: Std.Dev.0.61). This is probably because they found that learning how to use an e-learning system is easy. 
Table 2: Level of Perceived Ease of Use of E-learning

\begin{tabular}{|l|r|r|r|r|r|}
\hline & $\mathrm{N}$ & Minimum & Maximum & Mean & $\begin{array}{c}\text { Std. } \\
\text { Deviation }\end{array}$ \\
\hline I find e-learning system is easy to use & 50 & 1.00 & 5.00 & 3.9400 & .79308 \\
\hline $\begin{array}{l}\text { learning how to use an e-learning system is } \\
\text { easy for me }\end{array}$ & 50 & 2.00 & 5.00 & 4.0000 & .72843 \\
\hline $\begin{array}{l}\text { It is easy to become skilful at using an e- } \\
\text { learning system }\end{array}$ & 50 & 2.00 & 5.00 & 3.7800 & .67883 \\
\hline $\begin{array}{l}\text { I feel comfortable and confident when I use } \\
\text { e-learning }\end{array}$ & 50 & 1.00 & 5.00 & 3.7800 & .76372 \\
\hline $\begin{array}{l}\text { I learn better through online learning } \\
\text { compared to being in the classroom }\end{array}$ & 50 & 1.00 & 5.00 & 3.7000 & .83910 \\
\hline Total & 50 & 1.60 & 5.00 & 3.8400 & .61412 \\
\hline
\end{tabular}

As listed on the above table, the five (5) independent variables was tested in measuring the level of perceived ease of use of e-learning which each of them were found accepted by the students such as they found e-learning system is easy to use (mean=3.94), learning how to use an e-learning system is easy $(\mathrm{Mean}=4.0)$, it is easy to become skilful at using an elearning (Mean=3.78), they feel comfortable and confident when use e-learning (Mean= 3.78) and they learn better through online learning compared to being in the classroom $($ Mean=3.7).

Whereby in accessing the level of perceived of useful of e-learning, it was found that elearning is perceived positively useful for them (Mean=3.73: Std. Dev: 0.58). The students claim that e-learning makes it easier to study the course content. This might because of the accessibility of the system at any time and makes the students able to get insight on it easily.

Table 3: Level of Perceived Usefulness of E-learning

\begin{tabular}{|l|c|r|r|r|r|}
\hline & $\mathrm{N}$ & Minimum & Maximum & \multicolumn{1}{c|}{ Mean } & Std. Deviation \\
\hline $\begin{array}{l}\text { E-learning improve my } \\
\text { learning performance }\end{array}$ & 50 & 2.00 & 5.00 & 3.7200 & .70102 \\
\hline $\begin{array}{l}\text { E-learning increase my } \\
\text { academic performance }\end{array}$ & 50 & 2.00 & 5.00 & 3.7000 & .70711 \\
\hline $\begin{array}{l}\text { E-learning makes it easier } \\
\text { to study course content. }\end{array}$ & 50 & 2.00 & 5.00 & 3.8200 & .56025 \\
\hline $\begin{array}{l}\text { I use e-learning to acquire } \\
\text { the lecture notes from my } \\
\text { lecturer }\end{array}$ & 50 & 2.00 & 5.00 & 3.7400 & .80331 \\
\hline $\begin{array}{l}\text { I use the information in } \\
\text { the system in order to } \\
\text { prepare my assignment }\end{array}$ & 50 & 1.00 & 5.00 & 3.6800 & .79385 \\
\hline Total & 50 & 2.00 & 5.00 & 3.7320 & .58079 \\
\hline
\end{tabular}

The result revealed that the students perceived the e-learning is useful to them. (Mean=3.73: Std. Dev: 0.58). The students agreed that e-learning improve their learning performance (Mean=3.72), increase their academic performance (Mean=3.70), e-learning makes it easier to study course content (Mean=3.82), they use e-learning to acquire the lecture notes from 
their lecturer (Mean=3.74) and the students use the information in the system in order to prepare their assignment $($ Mean $=3.68)$.

The objective of this research is to investigate what determines a students' acceptance of an e-learning system, which after a consulting technology acceptance theory lead to two hypotheses based on TAM. In order to test these hypotheses, multiple regression analysis is used as analytical technique. In order to statistically test whether there is a positive direct relationship between the two independent variables perceived ease of use and perceived usefulness and the dependent variable attitude towards using e-learning, regression analysis using enter method was conducted. The regression shows that the hypothesized relationships are statistically significant $($ F-ratio $=12.888$, p-value $=.000)$. This regression model explains $32.7 \%$ of the variance in attitude. Therefore, only Perceived Usefulness of i-learn learning is the significant predictors to the attitude towards using e-learning $\left(t=3.679^{\prime} \mathrm{p}=\right.$ .001). Hence, only hypotheses $\mathrm{H} 2$ are accepted.

Table 4: Results of Regression Analysis: Dependent ATT, Independent PEOU and PU

\begin{tabular}{|c|c|c|c|c|}
\hline \multicolumn{2}{|l|}{} & Beta & $\mathrm{t}$ & $\mathrm{p}$-value \\
\hline 1 & (Constant) & & 3.487 & .001 \\
\hline & PEOU & .121 & .857 & .396 \\
\hline \multicolumn{1}{|c|}{ PU } & .519 & 3.679 & .001 \\
$\begin{array}{l}\text { Adjusted } \mathrm{R}^{2}=0.327 \\
\text { F-statistic }=12.888(\mathrm{p} \text {-value }=0.000)\end{array}$ & & \\
\hline
\end{tabular}

Table 4 above showed the resulting path coefficients of the proposed mode. Only hypotheses $\mathrm{H} 2$ are accepted by the data. The results show that perceived ease of use was not significantly influenced attitude of using e-learning $(\mathrm{r}=0.595, \mathrm{p}>0.05)$. Thus, the hypotheses H1 are not accepted.

Table 5: Results of Regression Analysis: Dependent BI, and PU

\begin{tabular}{|c|c|c|c|c|}
\hline & & Beta & $\mathrm{t}$ & $\mathrm{p}$-value \\
\hline 1 & (Constant) & & 1.399 & .168 \\
\hline & PU & .702 & 6.834 & .000 \\
\hline $\begin{array}{l}\mathrm{N}=50 \\
\text { Adjust } \\
\text { F-stati }\end{array}$ & $\begin{array}{l}3 \\
83 \\
4 \text { (p-value }=\end{array}$ & & & \\
\hline
\end{tabular}


The regression shows that the hypothesized relationships are statistically significant (F-ratio $=46.704$, p-value $=.000$ ). This regression model explains $48.3 \%$ of the variance in behavioural intention to use e-learning. Therefore, the intention toward using e-learning was influenced by perceived usefulness. Intention to use was found to be influence by perceived usefulness of i-learn learning $(r=0.493, p=0.000)$.

\section{Conclusions and Recommendations}

The success adoption and implementation of e-learning in all over the world nowadays had result the e-learning to remain as indispensable pedagogical phenomenon in the $21^{\text {st }}$ century and beyond. The utilisation of e-learning had cut distances to access lectures and learning materials, which faced during the conventional learning process. The result of this study also discovered that the Technology Acceptance Model (TAM) is a reliable model to identify the students' acceptance of e-learning in the UiTM Melaka. It goes without going that perceived usefulness, perceived ease of use and attitude toward e-learning use were found to be significant determinants of students' acceptance to use the e-learning. The e-learning system should focus on developing positive perceptions of e-learning usefulness and its ease of use as well as to encourage positive attitudes toward the system use among the students. The findings of this study also revealed that, in order to foster individual intention to use a technology, positive perception of the technology's usefulness is crucial, whereas the students' attitude toward using the technology may not be equally important. As the study revealed how effective the technology that had shaped the future for the education, the institution should consider improving the students' access to the Internet throughout the campus to maximize the potential of the system. The educator (lecturers) should become the driving force in ensuring technology integration for meaningful change and experts in pedagogical design which will ensure that the potential of technology use in education becomes recognised. The application of educational technology enhances skills and cognitive characteristics. With the help of new technology comes an explosion of learning and receiving new information, especially on mobile devices.

Moreover, the educator should advice the students to take advantage of the Internet to facilitate learning, searching learning object and knowledge management for e-learning. It will be helpful if the educators are able to educate the students to use the Internet wisely that will lead to their interest and keep using the e-learning in the future. The resistant to use the system can be reduce by delivering the adequate training on how to use the systems so that the students are well knowledgeable in the ICTs for proper operations of distance learning. The training and information sessions on e-learning need to focus primarily on how the elearning can help improve the efficiency and effectiveness of students' learning process.

The future study should expand the theoretical validity of the literature, and to cover broader aspect in making it is more reliable. The challenges of Industrial Revolution 4.0 should become the main focus in education field. As the researchers had already recognized limitations for this study, the researchers recommended future researcher to take this into consideration and to prepare themselves to minimize these limitations in the future. Because the respondents of this study were limited to the student from the Faculty of Business Management, additional samples from the other faculties are needed to generalize of the sample. It should cover larger samples of respondents as compared to this study which only manage to get 50 respondents. This is because the larger the population for the study, the better the results and its reliability can be more guaranteed. 
Because the questionnaire was the only method used in this study, there was a shortage that might reduce the reliability of the result of the study conducted. This was because the researchers really depended to the sincerity of the respondents to answer the questions. It was suggested that other methods could be applied for future research besides using questionnaires, for example conducting interviews or observation to make the study more comprehensive. The population of this study also became the limitation for this study, whereby an education system stands not only because of the educator solely, but also because of the availability of the institution, the management of institution and also the students and no holistic investigation could be conducted form their perspective because of the time constraint. The researchers hope that the future study could cover all the shortages in this study by extending the population including the students, the administrator officer, the policy makers of the educational institution and other who were directly involved in the educational system.

\section{References}

Adams, D. A., Nelson, R.R. and Todd, P.A. (1992). Perceived usefulness, ease of use, and usage of information technology: A replication. MIS Quarterly, 16(2), 227-247.

Asabere, N. and Enguah, S. (2012). Use of Information \& Communication Technology (ICT) inTertiary Education in Ghana: A Case Study of Electronic Learning (Elearning). International Journal of Information and Communication Technology Research. 2(1), pp.62-68.

Bagozzi, R. P.; Warshaw, P. R. (1992). Development and test of a theory of technological learning and usage. Human Relations 45(7): 660-686.

Barhoumi Chokri (2012). Factors influencing the adoption of the e-learning technology in teaching and learning by students of a university class. European Scientific Journal, $8(28), 1857-7881$.

Bingimlas, K., (2009). The barriers to the successful integration of ICT in teaching and learning environments: A review of the literature. Eurasia Journal of Mathematics, science and technology education, 5(3).

Bransford, J., Brown, A. L., \& Cocking, R. R. (Eds.). (2000). How people learn: brain, mind, experience, and school (2nd ed.). Washington, D.C.: National Academy Press.

Chen, S., Li, S \& Li, C. (2011). "Recent Related Research in Technology Acceptance Model: A literature Review". Australian Journal of Business and Management Research, 1 (9), pp.124-127.

Concannon, F., Flynn, A., \& Campbell, M. (2005). What Campus-Based Students Think about the Quality and Benefits of E-Learning. British Journal of Educational Technology, 36(3), 501-512.

Daugherty, M. K. (2015). A changing role for technology teacher education. Digital Library and Archives of the Virginia Tech University Libraries. Retrieved from http://scholar.lib.vt.edu/ejournals/JITE/v42n1/daugherty.html.

Davis, F. D., Bagozzi, R. P., and Warshaw, P. R. (1989). User acceptance of computer technology: a comparison of two theoretical models. Management Science, 35, 1989, 982-1003.

Davis, F.D. (1989). Perceived usefulness, perceived ease of use and user acceptance of information technology. MIS Quarterly, 13(3), 319-339.

Davis, F.D., Bagozzi, R.P., \& Warshaw, P.R. (1989). User acceptance of computer technology: a comparison of two theoretical models. Management Science, 35(8), 982-1003. 
Earle, R. (2002). The integration of instructional technology into public education: Promises and challenges. Educational Technology, 42, 5-13.

Fishbein, M. \& Ajzen, I. (1975), Belief, attitude, intention and behavior: an introduction to theory and research. Reading, MA: Addison-Wesley.

Fullan, M. (2000). The three stories of education reform. The Phi Delta Kappan, 81 (8), 581584. Retrieved from http://www.jstor.org/stable/2043973

Grandon, E., Alshare, O., \& Kwan, O. (2005). Factors influencing student intention to adopt online classes: A cross-cultural study. Journal of Computing Sciences in Colleges, 20(4), 46-56.

Greenhow, C., Robelia, B., \& Hughes, J. E. (2009). Web 2.0 and classroom research: What path should we take now? Educational Researcher, 38(4), 246-259.

Hair, J.F. Jr. , Anderson, R.E., Tatham, R.L., \& Black, W.C. (1998). Multivariate data analysis, (5th Edition). Upper Saddle River, NJ: Prentice Hall.

Hendrickson, A. R., Massey, P. D., Cronan, T. P. (1993). On the test-retest reliability of perceived usefulness and perceived ease of use scales. MIS Quarterly 17: 227-230.

Hu, P.J., Chau, P.Y.K., Sheng, O.R.L., \& Tam, K.Y. (1999). Examining the technology acceptance model using physical acceptance of telemedicine technology. Journal of Management Information Systems, 16(2), 91-112.

J. Gebhard, A. Grimm, L.M. Neugebauer, „Entwicklungen 4.0 - Ausblicke auf zukünftige Anforderungen an und Auswirkungenauf Arbeit und Ausbilung", in Journal of Technical Education,Vol. 3, 2015, pp. 45-61.

J. Nunnally (1978). Psychometric theory. McGraw-Hill, New York.

Jenkins, M. \& Hanson, J. (2003). E-learning series: A guide for senior managers. Learning and Teaching Support Network (LSTN) Generic Centre, United Kingdom.

Jenkins, M. \& Hanson, J. (2003). E-learning series: A guide for senior managers. Learning and Teaching Support Network (LSTN) Generic Centre, United Kingdom.

Kauffman, D. F. (2004). Self-regulated learning in web-based environments: Instructional tools designed to facilitate cognitive strategy use, metacognitive processing, and motivational beliefs. Journal of Educational Computing Research, 30, 139-161.

Krejcie, Robert V., Morgan \& Daryle W., (1970). Determining Sample Size for Research Activities. Educational and Psychological Measurement.

Koohang, A. \& Durante, A. (2003). Learners' perceptions toward the web-based distance learning activities/assignments portion of an undergraduate hybrid instructional model. Journal of Information Technology Education, 2, 105-113.

Koufaris, M. (2002). Applying the technology acceptance model and flow theory to online consumer behavior. Information Systems Research, 13 (2), 205-223.

Kozma, R. (Ed.) (2003). Technology and classroom practices: an international study. Journal on Research on Technology in Education.

Landry, B.J.L., Griffith, R. , \& Hartman, S. (2006). Measuring student perceptions of blackboard using the technology acceptance model. Decision Sciences, 4 (1), 87-99.

Lavanya B., Shylaja F. \& Santhosh M.S. (2017). Industry 4.0: The fourth industrial revolution. International Journal of Science, Engineering and Technology Research, $6(6), 104-106$.

Lee, H. W., Lim, K. Y., \& Grabowski, B. L. (2008). Generative learning: Principles and implications for making meaning. In M. J. Spector, D. M. Merrill, J. van Merrienboer \& M. P. Driscoll (Eds.), Handbook of research and educational communications and technology (3rd ed.). New York, NY: Taylor \& Francis Group.

Leidner, D.E. \& Jarvenpaa, S.L. (1993). The information age confronts education: case studies on electronic classrooms, Information Systems Research, 4, 24-55. 
Marketa Janikova \& Petra Kowalikova (2017). Technical education in the context of the Fourth Industrial Revolution. Open Online Journal for Research and Education, 1-9.

Maslin Masrom (2007). Technology acceptance model and e-learning. 12th International Conference on Education, Sultan Hassanal Bolkiah Institute of Education, Universiti Brunei Darussalam 21-24 May 2007.

Mathieson, K. (1991). Predicting user intentions:comparing the technology acceptance model with theory of planned behavior. Infromation Systems Research, 2(3), 173191.

Morris, M.G., \& Dillon, A. (1997). The influence of user perceptions on software utilization: application and evaluation of a theoretical model of technology acceptance. IEEE Software, 14(4), 56-75.

Morrison, G. R., Ross, S. M., Kemp, J. E., \& Kalman, H. (2010). Designing effective instruction: Applications of instructional design (6th. Ed.), New York, NY: Wiley.

Multimedia Development Corporation (2005). Malaysian Smart School Roadmap 20052020: An Educational Odyssey. Putrajaya:Government of Malaysia.

Multimedia Development Corporation (2006). Impact assessment study on the smart school integrated solution and other ICT initiatives. Putrajaya: Government of Malaysia.

OUM (2004). KTKM-OUM Research on E-Learning Readiness in Malaysia concept paper.

Park, S. (2009). "An Analysis of the Technology Acceptance Model in Understanding University Students' Behavioural Intention to Use e-Learning”. Education Technology \& Society, 12(3), pp.150-162.

S. Wong and T. Teo (2009). Determinants of the Intention to use Technology: Comparison between Malaysian and Singaporean female student teachers proceedings of the 17th international Conference on computers in education. Held in Hong Kong AsiaPacific Society, 2009, pp 784-791.

Segars, A. H.; Grover, V. (1993). Re-examining perceived ease of use and usefulness: A confirmatory factor analysis. MIS Quarterly 17: 517-525.

Smedley, J.K. (2010). Modelling the impact of knowledge management using technology. OR Insight (Dec 2010) Vol. 23, 4, 233-250. ISSN 0953-5543.

Subramanian, G. H. (1994). A replication of perceived usefulness and perceived ease of use measurement. Decision Sciences 25(5/6): 863-873.

Szajna, B. (1994). Software evaluation and choice: predictive evaluation of the Technology Acceptance Instrument. MIS Quarterly 18(3): 319-324.

Wong, S. L., Kamariah, A. B., \& Tang, S. H. (2006). Using a student centred learning (SCL) approach to teach a discrete information technology (IT) course: the effects on Malaysian pre-service teachers' attitudes toward IT. Technology, Pedagogy and Education. 15(2), 223-238.

Yi, M., \& Hwang, Y. (2003). Predicting the use of web-based information systems: Selfefficacy, enjoyment, learning goal orientation, and the technology acceptance model. International Journal of Human-Computer Studies, 59, 431-449. 